\title{
Propolis Counteracts Some Threats to Honey Bee Health
}

\author{
Michael Simone-Finstrom ${ }^{1, *}$, Renata S. Borba ${ }^{2,3}$, Michael Wilson ${ }^{4}$ and Marla Spivak ${ }^{5}$ \\ USDA-ARS Honey Bee Breeding, Genetics, and Physiology Laboratory, Baton Rouge, LA 70820, USA \\ 2 Centre for High-Throughput Biology, University of British Columbia, Vancouver, V6T 1Z4, Canada; \\ renata.borba@canada.ca \\ 3 Beaverlodge Research Farm, Agriculture and Agri-Food Canada, Beaverlodge, AB T0H 0C0, Canada \\ 4 Center for Drug Design, University of Minnesota, Minneapolis, MN 55018, USA; wils0888@umn.edu \\ 5 Department of Entomology, University of Minnesota, St. Paul, MN 55108, USA; spiva001@umn.edu \\ * Correspondence: michael.simonefinstrom@ars.usda.gov
}

Academic Editors: Steven Cook and Jay Daniel Evans

Received: 8 March 2017; Accepted: 21 April 2017; Published: 29 April 2017

\begin{abstract}
Honey bees (Apis mellifera) are constantly dealing with threats from pathogens, pests, pesticides and poor nutrition. It is critically important to understand how honey bees' natural immune responses (individual immunity) and collective behavioral defenses (social immunity) can improve bee health and productivity. One form of social immunity in honey bee colonies is the collection of antimicrobial plant resins and their use in the nest architecture as propolis. We review research on the constitutive benefits of propolis on the honey bee immune system, and its known therapeutic, colony-level effects against the pathogens Paenibacillus larvae and Ascosphaera apis. We also review the limited research on the effects of propolis against other pathogens, parasites and pests (Nosema, viruses, Varroa destructor, and hive beetles) and how propolis may enhance bee products such as royal jelly and honey. Although propolis may be a source of pesticide contamination, it also has the potential to be a detoxifying agent or primer of detoxification pathways, as well as increasing bee longevity via antioxidant-related pathways. Throughout this paper, we discuss opportunities for future research goals and present ways in which the beekeeping community can promote propolis use in standard colonies, as one way to improve and maintain colony health and resiliency.
\end{abstract}

Keywords: Apis mellifera; social immunity; plant resin; plant insect interactions

\section{Introduction}

Honey bee (Apis mellifera) populations in North America and Europe are currently experiencing high annual losses throughout the year due to various, often interacting factors including pathogens, parasites, pesticides, poor nutrition and management [1-4]. It is critically important to understand the impact of individual stressors and the interactions among stressors in order to develop solutions to increase colony health and survival. It is equally important to understand how honey bees' natural immune responses (individual immunity) and collective behavioural defenses (social immunity) can improve and maintain bee health and counteract stressors without human intervention. One form of social immunity in honey bee colonies is the formation of a propolis envelope within the nest that acts as an important antimicrobial layer. While a propolis envelope cannot mitigate all colony stressors, we review research to date on its known benefit to individual immunity and effect on reducing colony pathogen loads. We also suggest research avenues that could reveal additional ways propolis may improve colony health and resiliency. 


\subsection{The Role of Propolis in the Hive}

Propolis is the apicultural term for the plant resins that honey bees collect, bring back into the hive, and then deposit throughout the nest [5]. Resin-handling bees within the nest mix varying amounts of wax, which they produce themselves, with the resins during deposition $[5,6]$. The primary chemical components of propolis are derived from the plant-produced resins, though there is some evidence that honey bee glandular secretions (i.e., $\beta$-glucosidase) may also be added, potentially as an artifact of handling [7]. Various species across Hymenoptera (e.g., ants [8], stingless bees [9], and other Apis species $[10,11])$ collect and use resins for various purposes, including nest construction, and as a defense against predators, microbes and pathogens.

Honey bee colonies typically nest in tree hollows. Once a swarm (thousands of non-reproductive workers and one queen) finds a suitable cavity, they line the interior walls and often the nest entrance with a layer of propolis $0.3-0.5 \mathrm{~mm}$ thick [10]. This propolis envelope surrounds the colony and likely serves many non-mutually exclusive purposes, including waterproofing and preventing fungal decay of the hive walls $[5,12]$, reducing cracks and hive entrances, helping promote stable temperature and humidity through condensation [13], and reducing hive microbial loads [5,14]. In addition, there have now been several, mainly recent, studies examining the indirect and direct effects that propolis has on bees' immune systems, pathogens and parasites [5,14-22] (Figure 1).

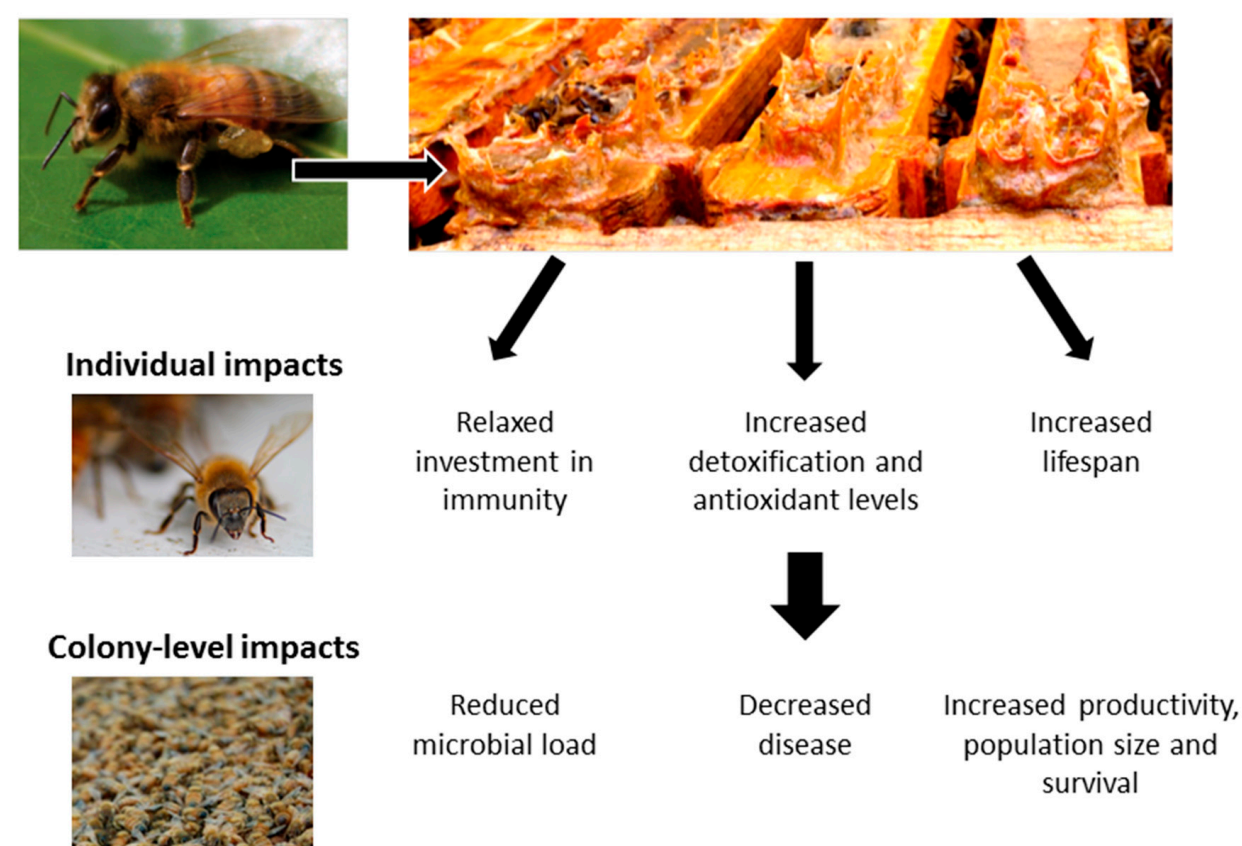

Figure 1. Overview of the impacts of honey bee-harvested plant resins on individual and colony health (photos by Michael Simone-Finstrom).

\subsection{Propolis as Social Immunity}

Social immunity describes cooperative behavioral defenses among members of a social group that result in the avoidance, control or elimination of parasitic infections [23]. A social immune system supplements and enhances the individual immune system, benefitting the health of a colony by decreasing the risk of microbe exposure and disease transmission among group members [24].

The nests of densely populated honey bee and other social insect colonies provide a favourable habitat for a wide range of parasites and pathogens [25] that have evolved to overwhelm or suppress their hosts' immune defenses. Honey bees were perhaps not subject to the multitude of pathogens and other stressors that confront them today within the context of modern beekeeping practices (e.g., transportation of hives, density of hives in close proximity, and exchange of comb across 
beekeeping operations [3]), but, as cavity nesters within trees, they likely encountered saprophytic, symbiotic and parasitic microbes and fungi. Some of these endemic microbes can induce an immune response in individual bees [26,27]. The evolution of resin use by honey bees could have been to combat fungal growth and potential fungal pathogens within the nest. Although both bacteria and fungi are common bee immune stressors, the honey bee immune system appears to be more attuned against bacterial pathogens [28]. One hypothesis is that social immune behaviors, such as the collection of plant resins and their deposition in the nest as an antimicrobial propolis envelope, evolved to compensate for deficiencies in innate or physiological immunity. Supporting this notion, there is some evidence that propolis may reduce impacts of mycotoxins produced by fungi [29]. In this case, feeding propolis extracts, rich in flavonoids and phenolic compounds, to adult honey bees reduced adverse effects of exposure to toxins produced by Aspergillus, a common hive fungus.

The immune system is the most costly physiological system in insects [30]. An elevated immune response can lead to reduced colony productivity in honey bees [31] and decreased individual survival in bumble bees [32]. Thus, it is not surprising that honey bees have evolved behavioral mechanisms of social immunity to reduce activation of the individual immune system against these microbes to ultimately benefit colony health [33-35].

\section{Constitutive Effects of Propolis on the Honey Bee Immune System}

Our experiments on the effects of resin on honey bee health followed findings of other researchers on the use of resin by social wood ants (Formica paralugubris) in Switzerland. This ant species constitutively collects spruce tree resins and places globules of resin near the brood, which results in reduced growth of microorganisms in the nest mound $[8,36]$, lower immune system activity of adult worker ants [37], and increased survival during pathogen challenge [38]. Based on these findings, we hypothesized that, for a honey bee colony, the antimicrobial properties of propolis would reduce the general microbial load within the nest cavity, thereby reducing the production of antimicrobial peptides by the innate immune system of individual bees. The first study to test if propolis exposure influenced honey bee immune function confirmed our prediction [14]. Bees were hived in small man-made bee boxes, enriched with an experimentally applied propolis envelope (ethanol extract of propolis painted inside the hive box; Figure 2A). Extracts were made from propolis previously collected from colonies at the University of Minnesota (resins collected mostly from plants in the genus Populus [17]), or from Brazilian green propolis (from the tropical shrub Baccharis dracunculifolia [39]). General bacterial loads (16S rRNA expression) and transcription levels of the gene encoding for the antimicrobial peptide, hymenoptaecin, and a gene involved in cellular immunity, AmEater, were found in significantly reduced quantities in seven-day-old bees from colonies with the propolis-extract envelope compared to bees in colonies with no propolis envelope. In summary, bees in colonies with the propolis-extract envelope had an overall reduction in general bacterial loads, and a corresponding lower investment in immune gene expression compared to bees in boxes without the propolis envelope [14].

A second study [20] also confirmed the prediction that bees in colonies with a propolis envelope had reduced investment in individual bee immune function, but, in contrast to Simone et al. [14], no reduction in overall bacterial load was observed. The methods of the second study differed: rather than painting a propolis-extract envelope within the bee boxes, the colonies were allowed to deposit their own propolis envelope from resins collected within a foraging range of the University of Minnesota. Twenty-four colonies were hived from "packages" (10,000 bees and a mated queen) in new Langstroth bee boxes. Twelve of the colonies were hived in boxes fitted with commercial propolis traps (plastic grids) along all inner walls of the brood boxes, which stimulated the bees to form a propolis envelope (Figure $2 \mathrm{~B}$ ). The effect of the propolis envelope on colony strength and health, and on individual bee immune function was measured over a full year. As a validation of our methods, the entire experiment was repeated a second year using 24 new colonies. The expression of immune-related genes, particularly hymenoptaecin and abaecin, of individual seven-day-old bees was significantly lower over the entire foraging season in colonies with a propolis envelope in both trials, indicating the 
long-term effect of the propolis on baseline expression of immune-related genes [20]. By the following spring, there were no significant differences in gene expression levels for most immune genes between bees from the two treatment groups. The effect on the immune system was diminished [20], likely due to the decrease in biological activity of the propolis during the winter months when bees were not foraging or seasonal variation in availability of resin sources in early spring, which can vary in active compounds [20,40,41]. Presumably, when the growing season commenced, bees would add new propolis on top of the old and restore the antimicrobial properties of the envelope. Bees in colonies with a propolis envelope did have significantly higher levels of the blood storage protein vitellogenin $(\mathrm{Vg})$ compared to control colonies in spring of both years. Higher levels of $\mathrm{Vg}$ are an indicator of well-nourished bees [42-44]. A decrease in energetic costs associated with the maintenance of an efficient immune system during the foraging season might help bees maintain higher storage protein levels (e.g., vitellogenin) required for overwintering success [45] and allocate energy to perform vital tasks the next spring (e.g., foraging, rearing brood).
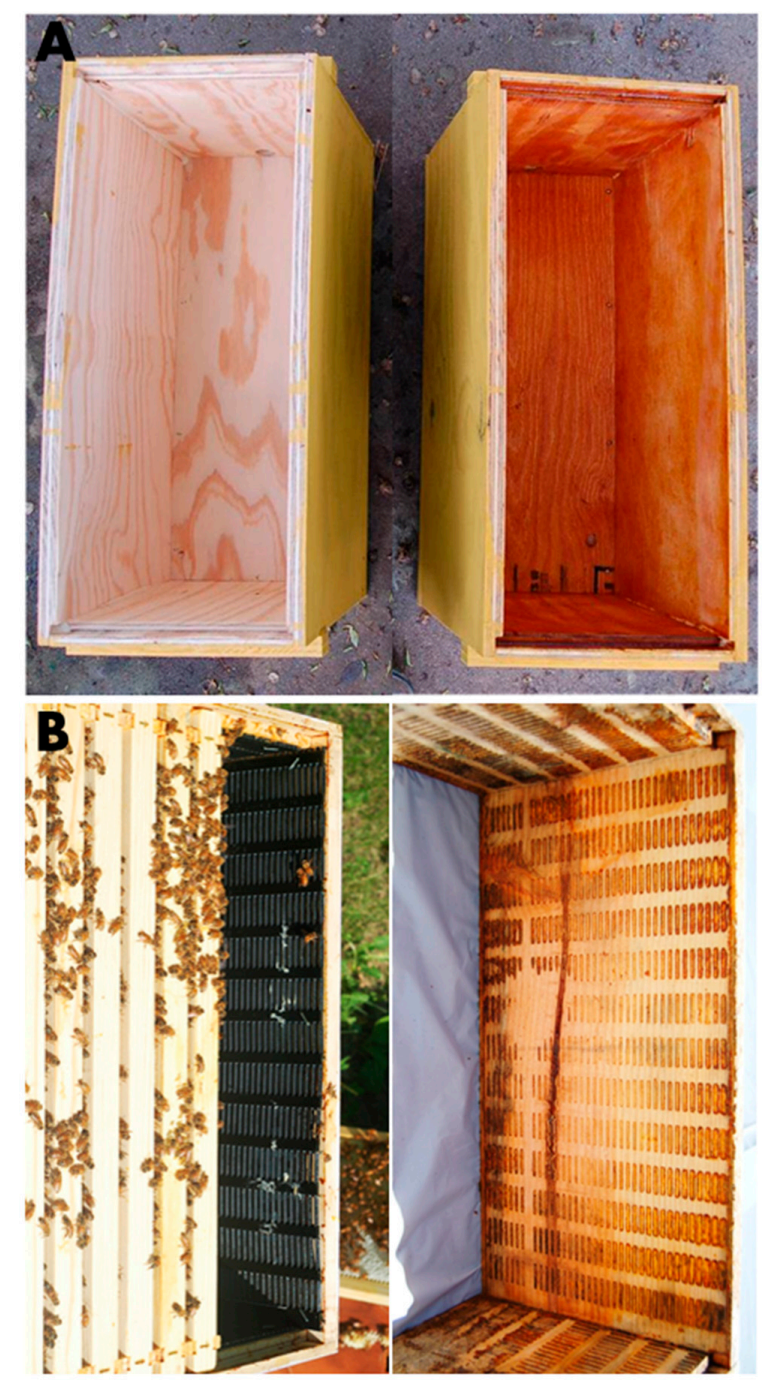

Figure 2. Examples of propolis envelopes in managed hives. (A) a propolis extract was used to "varnish" the interior hive body walls. The left was treated with $70 \%$ ethanol, the solvent for the extract, while the right was treated with poplar-derived propolis extract (photos by Michael Simone-Finstrom). (B) commercially purchased "propolis traps" were cut and stapled to the interior walls (left). Once the bees deposit sufficient propolis in the trap, the trap can be removed leaving the propolis attached to the wall (right; photos by Renata S. Borba). 
The results of these two experiments demonstrated that costly immune gene expression in bees was lowered by the presence of the propolis envelope within the nest, but clear effects of propolis on colony fitness were not observed. We did not measure the effects of propolis envelope on individual bee fitness, which, in retrospect, may have been more revealing. Nicodemo et al. [18] found positive effects of propolis on individual bee fitness by measuring brood viability and adult bee longevity of Africanized honey bee colonies, an A. mellifera subspecies notable for depositing high amounts of propolis in some naturally selected colonies and those bred for increased propolis use due to industry export demands [18,46-48]. Colonies selected for high propolis collection for one generation produced 34 times more propolis compared to colonies selected for low propolis collection, consistent with the high heritability estimates for propolis collection ranging from 0.66 [49] to 0.87 [46]. Brood survival rates (survival from egg to adult stage) and individual adult bee longevity were both significantly higher in the high-propolis collecting colonies. The effects of propolis on colony-level measures have been less clear [46-49]. High propolis collecting colonies had more pollen and honey stores within the nest in some experiments [47-49] (but see [46]); it is unclear, however, if high propolis collection was correlated with foraging rates in general in these experiments. Bees within the high propolis collecting colonies also exhibited increased hygienic behaviour [46,48,49], assayed by the rate of removal of pin-killed brood (a proxy for removal of diseased, parasitized and dead brood), although there were no differences in levels of Varroa mites between sets of colonies [49].

Future studies might continue the work of Borba et al. [20] to examine the effect of the propolis envelope on better metrics of colony-level fitness such as queen longevity or colony reproduction (swarming) and survivorship, particularly for European honey bees. Furthermore, the potential benefits of propolis enrichment for colonies in a commercial, migratory or honey production operation need to be explored more fully. For the effects of propolis on the fitness of individual bees, experiments could investigate whether the reduced investment in immune function by individual bees after exposure to propolis corresponds with increased bee weight at emergence and longevity.

\section{Does Propolis Suppress Immune Function?}

The reduction in immune function observed in bees surrounded by a propolis envelope $[14,20]$ does not imply the bees' immune system was suppressed or inhibited. A recent study using honey bees maintained in "bee cups" coated with propolis extracts collected from North Dakota or left propolis-poor by coating with an equal amount of $70 \%$ Ethanol (the solvent of the extracts), confirmed that propolis does not cause immune suppression [50]. Individual, newly emerged bees were fed either $2 \mu \mathrm{L}$ of sucrose solution (unchallenged controls) or $2 \mu \mathrm{L}$ of sucrose containing $40 \mathrm{mg}$ of lipopolysaccharides (LPS) from Escherichia coli (challenged). LPS is the major outer surface membrane component of Gram-negative bacteria and a known immune-stimulant for honey bees (and other insects [51,52]), and, as such, acts to activate the immune system without creating an active infection. Analysis of immune gene expression of individual bees from the cages showed bees exposed to propolis from North Dakota had an enhanced immune response in challenged individuals relative to unchallenged controls for the genes encoding the antimicrobial peptides defensin 1 and abaecin (Figure 3; [50]). Unchallenged control or challenged LPS-fed bees were also monitored for survival. Immune activation via LPS significantly reduced lifespan of all bees, but there was no effect of propolis exposure (Figure 4; [50]). While, in this controlled cage study, a general reduction in immune gene expression was not observed as in colony-level field exposures [14,20], this could be due to the sterile environment of the incubator cages. Earlier work suggested that the reduction in immune gene expression could be, at least in part, due to the reduction of hive microbes [14] (but, see [20]), which would not be present in the incubator cages. In summary, the challenged bees in a propolis-enriched environment had an increased immune response compared to challenged bees in the cage environment with no propolis, indicating that the presence of propolis does not appear to directly suppress the immune system. Recent evidence suggests that at least some components of propolis may be able to influence lifespan in the cage setting, as bees fed with $p$-coumaric acid and 
quercetin, common phytochemicals in hive products like propolis, had longer lifespans compared to control bees under specific conditions. Though exposure to propolis volatiles in the cage study did not affect lifespan (Figure 4), possibly due to smaller samples sizes than those in the recent cage study with oral treatments [53], it remains to be verified if propolis exposure or hive supplementation in general increases lifespan of individual bees under more realistic conditions, as observed by Nicodemo et. al. [18] in Africanized honey bees bred for increased propolis production.

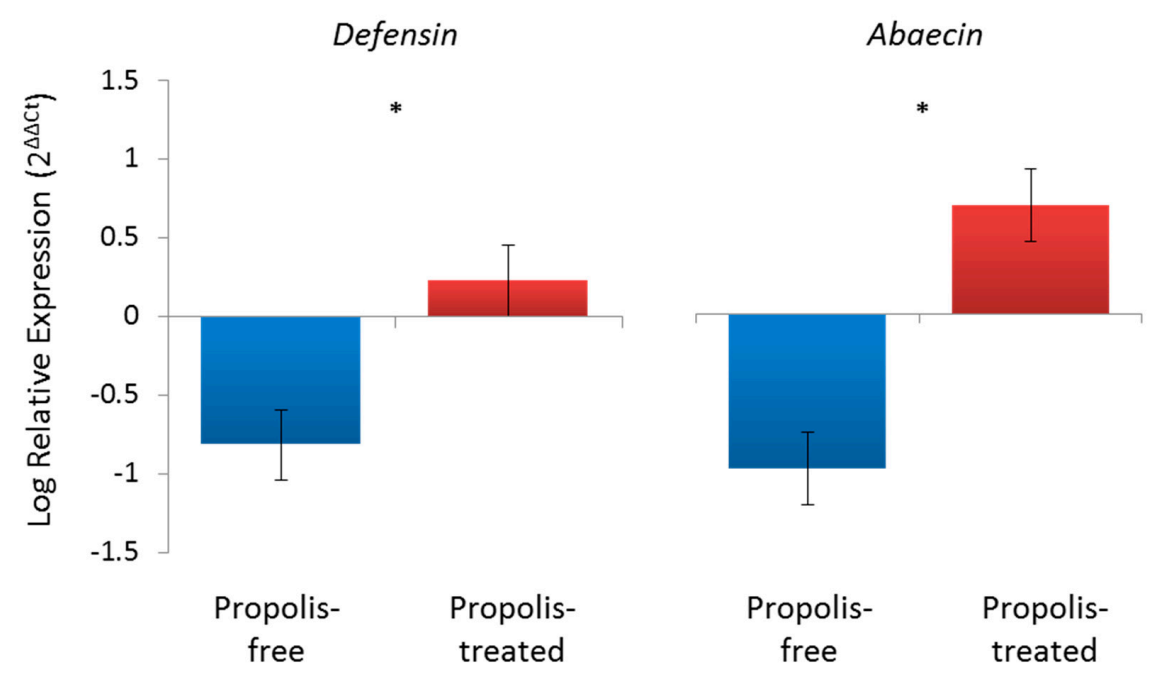

Figure 3. Propolis exposure may boost individual immunity when challenged. The log relative expression was calculated using the $\Delta \Delta \mathrm{Ct}$ method [54] with expression for LPS-fed bees is shown relative to expression of unchallenged control bees for the propolis-free and propolis-treated cages. Expression of the antimicrobial peptides is relative to the reference $\beta$-actin. The propolis-treated cages resulted in a significant increase in immune gene expression in LPS-fed, immune-challenged bees for both defensin $\left(F_{1,31}=12.46, p=0.001\right)$ and abaecin $\left(F_{1,31}=9.06, p=0.005\right)$, as indicated by the "** between treatment groups. $n=15$ bees per treatment group.

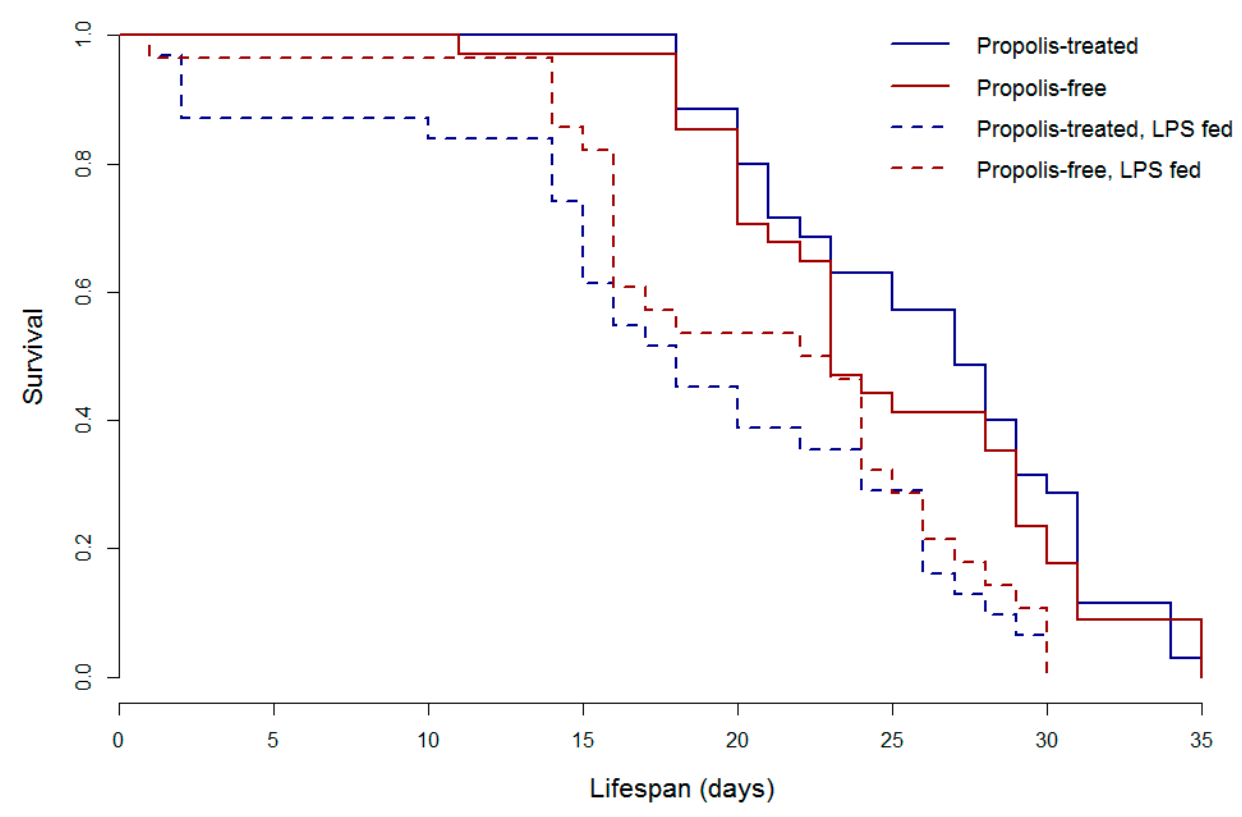

Figure 4. Immune challenge reduces honey bee lifespan in caged bees (Wald $\mathrm{X}^{2}=14.18, p=0.002$ ). In the incubator setting, which is likely more stressful than a hive, there was no effect of the propolis enriched environment on lifespan $(p=0.83) . n=35$ bees per treatment group. 
Bees' exposure to propolis may also "prime" the immune system in the way that it appears to prime detoxification pathways, at least for experiments involving oral doses of propolis extracts or chemical components $[29,55,56]$. In another field-based experiment, colonies with and without a natural propolis envelope were either challenged or not with spores of a honey bee bacterial pathogen, Paenibacillus larvae (see section below for details, [19]). In the presence of clinical signs of the disease, adult bees showed significantly higher expression of two antimicrobial peptides, hymenoptaecin and apidaecin, compared to bees in colonies without a propolis envelope. This further provides support that the immune system is not supressed when bees are exposed to propolis, but simply can allow for a reduced investment in immune expression when unchallenged [14,20]. In fact, bees in an environment with propolis invested more in the production of antimicrobial peptides when the colony was exposed to pathogenic microbes compared to same-aged bees in colonies without propolis [19], similar to what was found in the cage study (Figure 3). Individual investment in inducible immune defences (e.g., antimicrobial peptide production) therefore may be at least somewhat context dependent on the colony investment in constitutive defenses (i.e., propolis deposition; [34]), given that reliance on both types of broad immune defenses may also be regulated by type of pathogen exposure [57]. Thus, the propolis envelope can be viewed as an external and vital component of the bees' immune defense and the colony's social immunity.

\section{The Effect of Propolis against Pathogens}

The majority of propolis-related research has focused on identifying chemical components, and understanding the bioactivity of whole extracts, fractions and specific compounds. Much of this is in relation to identifying novel compounds that could be used for human health applications [58-62]. Several reviews have examined this subject over the years, consistently updating the numbers of new chemical compounds being discovered in propolis samples collected across the globe and often including measures of biological activity. Over 300 compounds with variable biological activities have been identified in propolis samples [63] (see Box 1).

Box 1. Highlight of recent work to identify the major bioactive components of propolis

Propolis is a rich and diverse source of biologically active compounds due to the diversity of resin-producing plants throughout the world [64]. Propolis has been widely investigated for compounds useful to human health and is regularly screened for cytotoxicity, antibacterial, and antifungal activity. In addition, propolis has been studied for its effects on the immune system and anti-protozoal activity. Several flavonoids and their esters isolated from Sonoran propolis induce apoptosis in a $\beta$-cell lymphoma cell line [65], while the polyisoprenylated benzophenone nemorosone from Clusia-derived Cuban propolis is cytotoxic against four different cancer cell lines [66]. Prenylated cinnamic acids isolated from Brazilian propolis [67] and terpenes isolated from both Brazilian propolis and Cretan propolis [68] have reported antimicrobial activity against bacterial and/or fungal pathogens. These compounds from Brazilian and Cretan propolis originated from Baccharis dracunculifolia and likely Cupressaceae conifers, respectively [69]. Caffeic acid phenethyl ester (CAPE) from poplar-derived propolis has been a target of much interest, as it appears to be a major factor modulating anti-inflammatory and immunomodulatory properties of some propolis varieties [61]. Lastly, diterpenes from Libyan propolis were found to have antiprotozoal activity against Trypanosoma brucei and Leishmania donovani [70].

Recent studies have also focused on propolis compounds important for bee health, with an emphasis on brood diseases. Several known compounds with activity against $P$. larvae have been isolated from Bulgarian propolis including pinocembrin, pinobanksin-3-acetate, and a mixture of caffeic acid esters [71]. However, these compounds may not be responsible for the majority of anti-P. larvae activity observed in U.S. propolis samples [21]. Using bioassay-guided fractionation, Wilson et al. [72] isolated pinobanksin-3-octanoate and five other 3-acyl-dihydroflavonols that showed inhibitory activity against both $P$. larvae and A. apis. These 3-acyl-dihydroflavonols originated from Populus fremontii resin, but varying amounts were also found in other North American Populus resins. The amount of pinobanksin-3-octanoate and pinobanksin-3-hexanoate in regional samples of U.S. propolis was strongly correlated with anti-P. larvae activity, suggesting that these compounds could be markers of anti-P. larvae activity. Voigt and Rademacher [73] found that the common propolis phenolics cinnamic acid and pinocembrin had a fungistatic effect on $A$. apis. We do not understand how propolis compounds interact with bee pathogens in the hive, so this question should be a priority in future studies. 
Propolis is most well-known for its antimicrobial activity against a number of bacterial, fungal and viral pathogens, particularly human pathogens [74-77]. A honey bee colony collects resin from multiple plant sources, though there is likely source fidelity for individual bees [5,17]. The antimicrobial activity of the propolis depends on the antimicrobial properties of its source plant resins [21,72], and the fact that colonies mix sources of resins creates an extremely complex mixture against which susceptible parasites and pathogens would have difficulty developing resistance. A previous study investigating the biological activity of single and multiple-resin source against stingless bee parasites and pathogens showed that, although some single-resin sources may be more effective against a single parasite or pathogen, mixed sources are considerably more effective overall due to increased variety of chemical compounds [78].

The therapeutic value of propolis for honey bees has been understudied. Most studies have concentrated on the high in vitro activity of propolis from various regions of the world against two pathogens: Paenibacillus larvae, the causative agent of American foulbrood (AFB) [15,19,21,79-81]; and Ascosphaera apis, the fungal agent of chalkbrood disease [16,21,73]. Early studies on the therapeutic effects of propolis on individual bees and colonies yielded positive results when propolis was fed to the bees in sugar solution (e.g., [80,81]). In these studies, clinical signs of AFB in field colonies, and number of $P$. larvae spores in honey stores were reduced when bees were fed propolis in sugar syrup. Feeding bees propolis would be similar to administering oral antibiotics, but as the antimicrobial properties of propolis vary widely across plant sources and regions, oral application risks under- or over-dosing the bees and potentially harming the beneficial microbiota in bees' guts [82]. To our knowledge, honey bees do not naturally consume propolis. Therefore, the mode of action of a therapeutic effect of propolis on colony pathogens is probably via volatile compounds [83] or direct contact [84] either on the hive walls, a barrier at the nest entrance, or along the rims of comb cells.

Our in vivo studies at the colony level first examined the effectiveness of the propolis envelope within the nest to reduce chalkbrood infection [16]. Chalkbrood is one of the major fungal diseases affecting honey bees, which only infects the larval stage [85]. Adult bees are carriers of the fungal spores and feed young larvae contaminated brood food, presumably by adding nectar from the bee crop contaminated with spores into brood food. Alternatively, the food fed to young larvae may become contaminated with fungal spores left in the wax comb from a previous infection in the colony. As the larva develops, the spores germinate in the gut and eventually penetrate into the hemocoel, overwhelming the bee with mycelia and turning it into a "chalkbrood mummy." In one field test of potential effects of propolis against chalkbrood, colonies were either enriched with an experimentally applied propolis envelope (ethanol extract of Minnesota-derived propolis painted inside the hive box) or not propolis-enriched (as in Figure 2A). Colonies were then challenged by feeding them pollen patties containing $A$. apis spores, prepared by homogenizing chalkbrood mummies in the pollen [86]. After three weeks, the colonies with a propolis envelope had significantly fewer chalkbrood mummies in the combs $(14.7+7.5$ mummies; $n=6$ colonies $)$, compared to colonies without the propolis envelope (108.2 +40.0 mummies, $n=6$ colonies) [16]. One known mechanism of resistance to chalkbrood disease is through hygienic behaviour, whereby the adult bees detect and quickly remove chalkbrood-infected brood from the nest before the pathogen becomes infectious [86]. In this experiment, none of the colonies were considered hygienic, as determined by freeze-killed brood assay (reviewed in [33]); thus, the difference in disease levels between the two sets of colonies was not due to differences in hygienic behaviour. While in vitro work has shown that propolis extracts do directly inhibit growth of $A$. apis in liquid media [21], the mode of action for how the propolis extract painted on the inside of the bee box reduced fungal infection in the larvae, maintained mainly in the center of the nest, remains unknown.

In subsequent tests, the effectiveness of the propolis envelope to reduce severity of AFB, which is similar in etiology to chalkbrood disease, was examined [19]. Adult bees are only the carriers of P. larvae spores and are not susceptible to infection. As with chalkbrood, young larvae may become infected via contaminated larval food fed by adult bees, or the larval food may become contaminated with spores already in the wax comb. Bees resist AFB infection in a number of ways: in addition 
to hygienic behaviour of adult bees toward infected larvae $[87,88]$, some larvae demonstrate genetic resistance against $P$. larvae $[89,90]$, and young adult bees from some genetic lines secrete antimicrobial compounds into larval food, which protect the larvae from infection [91,92]. Our experiment consisted of challenging non-hygienic colonies in the field by spraying combs with sugar solution that contained spores of P. larvae (following [93,94]). Five challenged colonies were fitted with commercial propolis traps along all inner walls of the brood boxes, stimulating the bees to form a natural propolis envelope as in Borba et al. [20] (Figure 2B), and five other challenged colonies were not provided with propolis traps and did not construct a propolis envelope. We investigated the effects of the propolis envelope on the overall reduction of clinical signs of AFB, and on the antimicrobial activity of larval food fed to 1-2 day old larvae. The presence of the propolis envelope did not completely clear AFB infection; all colonies had clinical signs two months later at the end of the experiment, similar to early studies (e.g., [80]). However, the severity of AFB, in colonies with a propolis envelope was relatively mild (severity score just over 1, equating to 1-5 infected larvae per comb, following [87]) compared to the colonies without the propolis envelope (severity score just over 2, or 6-25 infected larvae per comb). Moreover, the ability of the larval food from challenged colonies with a propolis envelope to inhibit the growth of P. larvae, in vitro, was significantly higher compared to the activity of larval food from challenged colonies without a propolis envelope [19]. It is unclear if the increased antimicrobial activity of the larval food was due to the presence of antimicrobial peptides produced by adult bees and incorporated into larval food, or to the presence of compounds from the propolis in the food. Since antimicrobial peptides and other antimicrobials (e.g., glucose oxidase) are secreted by nurse bees into brood food, the same mechanism that allows adult bees to alter investment in innate immunity may allow nurse bees to invest more in these compounds as a social immune defense [95]. These studies emphasize the critical importance of the propolis envelope to honey bees' health and demonstrate its role in larval defense against bacterial infections.

Field experiments have also provided evidence of self-medication in honey bees as the rate of resin foraging increased in colonies after challenge with the fungal pathogen, $A$. apis. Colonies have been shown to consistently increase the number of resin foragers after a colony-level infection with A. apis over several years of study $[16,19]$. This case of self-medication is particularly interesting because it occurs at the colony level and does not simply involve individuals ingesting compounds to self-medicate themselves [96]. Because only larvae are infected by A. apis, the increased resin collection is a great example of a social immune response increasing collection of antimicrobial products by adult bees to protect younger nestmates. Subsequent studies have determined that this self-medication behavior is pathogen-specific and does not occur for colony-level infections with the bacterial brood disease AFB [16,19]. This finding makes the response to chalkbrood all the more interesting and raises questions related to the mechanisms regulating the behavioural change and how colonies may differentially invest in social and physiological immune defences against fungal versus bacterial pathogens.

\section{Effect of Propolis on Other Bee Pathogens, Parasites and Pests}

Honey bee colonies are susceptible to various pathogens, parasites and pests [85,97]. The main health threats contributing to colony losses include the microsporidian gut parasite Nosema spp., the ectoparasitic mite Varroa destructor, and some of the 20 viruses known to infect bees [97]. Other secondary pests can kill weakened hives and destroy hive products, such as the greater wax moth, small hive beetle, and small rodents.

\subsection{Nosema Ceranae}

Nosema ceranae is a gut parasite of honey bees. This parasite was originally found in Asian honey bees, Apis cerana, and recently described in European honey bees, A. mellifera [98]. In the last 15 years, N. ceranae has spread throughout Europe and the U.S and largely replaced N. apis in these two regions $[98,99]$. To our knowledge, no studies have investigated the effects of propolis on Nosema spp. 
infection in honey bees (A. mellifera). However, two studies have investigated the effect of stingless bee (Trigona apicalis) propolis on N. ceranae infections in A. cerana [100] and A. florea [101]. While the methods used in these experiments are not ideal to fully answer the question because of the origin of propolis and the propolis extraction methods, they raise interesting questions that should be explored further. In both studies, individual bees were inoculated per os with sucrose solution containing spores of N. ceranae. After inoculation, bees were fed propolis extract in water. Similar results were found in both experiments: all challenged bees treated with propolis lived longer than untreated challenged bees (but not longer than unchallenged bees), and those fed with a high concentration of propolis (a $50 \%$ solution of propolis extract $-60 \mathrm{~g}$ propolis $/ 100 \mathrm{~mL}$ ethanol—in sugar syrup) had lower infection rate [100]. These studies provide a starting point to investigate the biological relevance of these findings within an A. mellifera colony and how propolis in the nest environment may also be impacting gut parasites. The results indicate that propolis may have toxicity to this gut pathogen, but also raises concerns about toxicity to beneficial microbiota in bees' guts, and whether the natural mode of action is per os. This issue is of particular relevance since the bee microbiome consists of a large proportion of gram-positive bacteria [102], and propolis is generally more effective against Gram-positve bacteria verus Gram-negative bacteria [41].

\subsection{Varroa Destructor}

Of considerable interest is whether propolis has biological activity against Varroa destructor. A series of laboratory assays have shown that directly exposing mites held in Petri dishes to relatively low concentrations of ethanolic propolis extracts causes high mite mortality [22,84,103-105]. Ethanolic extracts from German propolis caused $100 \%$ mortality due to contact with $10 \%$ propolis extract [84]. Furthermore, mite exposure to extracts at concentrations as low as $0.5 \%$ caused narcotic effects leading to reduced heat production and metabolic rates [84,103]. Sublethal effects of low concentrations of propolis may debilitate a Varroa mite's mobility, as well as make them less capable of dealing with environmental stressors (e.g., high temperatures [103]). Moreover, ethanolic extracts from Argentina also caused narcotic effects and significantly higher mite mortality $(60.5 \%$ to $90 \%)$ compared to control treatments [105]. However, a recent study using raw propolis, not extracts, found no effect of propolis exposure on mite survival in the laboratory [22]. Given that ethanolic extractions of propolis are essentially chemically enriched fractions because they contain no wax, it is unclear when using raw propolis how much of the material is bioactive. Furthermore, the propolis used in the study was a year old and so likely lost a portion of its bioactive compounds. With all of this in mind, effects of more natural applications of propolis versus Varroa need to be explored. Furthermore, differences in the acaricidal effects of German and Argentinian propolis in these studies may be due to the differences in the concentration of compounds, the botanical origin and, more importantly, the chemical properties of the propolis from these two regions. With respect to colony-level differences in chemical composition of propolis, Popova et al. [106] showed that propolis from colonies able to maintain very low mite infestation levels without acaracide treatment were distinct in its chemical composition compared to propolis from colonies with high level of mites. Propolis from mite-tolerant colonies had significantly higher concentration of four compounds (i.e., caffeic acids and pentenyl caffeates). Borba et al. [20] found no differences in mite levels between large field colonies with a propolis envelope and those without an envelope over two years of study.

\subsection{Viruses}

Related to Varroa are the numerous honey bee viruses that can be transmitted through mite infestation, but also are transmitted horizontally from worker to worker or vertically via the queen. Since propolis has known activity against several viruses of human interest (reviewed in [62]), there has been considerable interest in potential effects of propolis against bee viruses, despite little study on the subject. Current evidence suggests that the presence of a propolis envelope within the honey bee nest cavity may not influence viral loads. Borba et al. [20] found no difference in the viral loads of 
deformed wing virus (DWV), black queen cell virus or Israeli acute bee paralysis virus in bees from propolis-rich or propolis-poor colonies in fall or spring over two years of study. However, a recent study suggests that increased propolis in colonies may impact the levels of DWV, but not sacbrood virus [22]. When raw propolis was added to the tops of colonies, DWV levels did not increase with mite infestation as was expected and observed in the propolis-deprived colonies [22]. Furthermore, they show data that indicates that colonies increase the rate of resin foraging in relation to DWV infection. Given the low mite levels in these colonies overall and the fact that they were previously treated with miticides, these intriguing findings warrant further investigation. Particularly, future work should aim to disentangle the combined effects of DWV-infection and Varroa infestation on resin foraging behaviour.

\subsection{Other Hive Pests}

In regard to other hive pests, two studies have examined the effectiveness of propolis extracts against the greater wax moth (Galleria mellonella), an opportunistic pest that mainly affects weakened hives $[107,108]$. Propolis extract concentrations of $4 \%-10 \%$ (g propolis $/ 100 \mathrm{~mL}$ ethanol) showed high toxicity to G. mellonella when early stage larval instars had direct contact with the propolis solution for $30 \mathrm{~s}$ [108]. Lower concentrations of propolis extract showed sub-lethal effects by reducing pupal metamorphosis duration. However, when fractionated propolis $(80 \%$ methanol extraction of propolis followed by physical and chemical fractionation) was added to artificial diet fed to G. mellonella, it did not influence larval growth, and no toxic effect was observed [107]. The lack of propolis fractions toxicity to G. mellonella when mixed into food indicates that this species may tolerate low concentrations of phenolics in their diet. This is not unusual in lepidopterans as other species in this family have also shown tolerance to some flavonoids (quercetin and rutin [109]) and, in some cases, the presence of flavonoids in the diet improves the performance of silkworms (Bombyx mori [110]).

Cape honey bees, A.m. capensis, have been observed encapsulating the parasitic small hive beetle, Aethina tumida, in "propolis prisons", which serves to prevent the beetles from successfully reproducing [111,112]. The extent of this behavior in other subspecies has not been fully investigated, but it is not a trait unique to the Cape honey bee and has been noted to be variably expressed in European honey bee colonies $[113,114]$. The European honey bee, A. mellifera, will also embalm other intruders that are presumably too large to remove from the nest after being killed [5]. Hoyt [115] observed a mouse encased in propolis and suggested that the bees covered it in propolis to prevent odor and decay from affecting the rest of the hive.

\section{Propolis and Pesticides}

Another area of special interest to the beekeeping community is the presence of contaminants in-hive products, like propolis (i.e., [116]). While commercial hives are often given a variety of chemical treatments to control various hive diseases and parasites, investigations into the residues that these may leave behind are relatively new. There is limited evidence that acaricides can occasionally be found in propolis collected from a hive $[22,117,118]$, as well as the antibiotic (tylosin) used to treat the bacterial diseases American foulbrood and European foulbrood (two of 30 samples from China had detectable amounts [119]). Similarly low levels of pesticide residues likely from treatments on the plant sources or contaminated pollen have been detected in some propolis samples [120,121], but not in others $[122,123]$. Further study on the frequency and abundance of these chemicals in propolis samples needs to be conducted as well as the possible antagonistic effect that these compounds could have on the chemical constituents of propolis or possibly the synergistic effects that the residues have with those chemicals found in wax, honey and pollen stores (i.e., [124,125]).

Recent evidence also indicates that honey bees may "entomb" fungicide-contaminated pollen in cells with propolis, but the frequency of this behavior and subsequent effect on colony health is currently unclear [126]. Older comb tends to have more "entombed" cells and a regular rotation of new comb into beekeeping operations would reduce the presence of these cells in colonies. It also 
raises the question of how bees manipulate contaminated propolis samples and they simply layer more propolis over contaminated areas. One other example seen during mite treatments with thymol products is that colonies often surround the thymol tray in a thick layer of propolis, entirely encasing it on occasion (Figure 5). It is unclear if they reuse and redistribute this propolis once the treatment is gone and if it could extend the length of the treatment or cause other negative effects at the colony level. One recent study suggests that propolis could be a "reservoir" of miticides. Varroa exposed in a laboratory setting to propolis harvested from a thymol-treated colony had higher mortality than mites exposed to propolis from an untreated colony, even though the propolis was tested a year after collection [22]. This result and the potential impacts warrant further study.

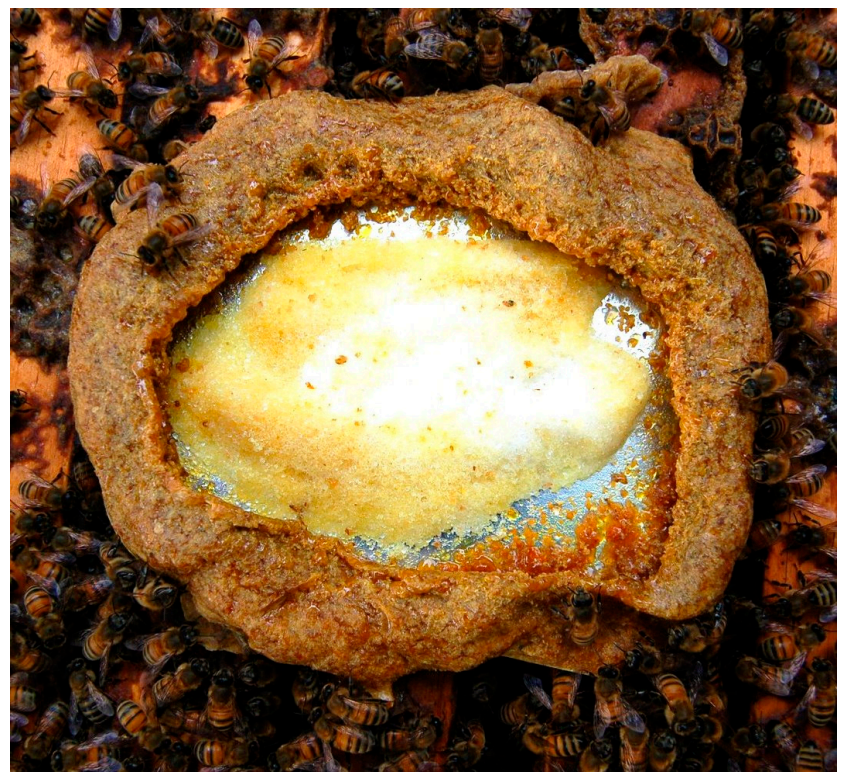

Figure 5. Thymol treatment on the top of a hive encased by propolis. Bees can be seen surrounding the tray with the miticide with a wall of propolis. (Photo by Michael Simone-Finstrom).

\section{Propolis and Other Aspects of Bee Health}

It is possible that the antimicrobial properties of materials used and stored in combs (e.g., royal jelly, honey) are enhanced by the addition of propolis [8,98]. Current work showing the effect of a propolis-enriched environment on the antimicrobial activity of larval food continues to raise this possibility [19]. Additionally, it has been suggested that some of the phenolic compounds present in honey may be derived from propolis itself [55]. Depending on how much propolis is incorporated into the comb or along the rims of cells, which is seen in feral colonies and in some managed colonies [5,127], the potential of propolis-related compounds and volatiles "leeching" into other hive products remains a possibility and needs to be further examined. Alternatively, honey bees could potentially actively "enhance" the antimicrobial activity of propolis or these other hive products by combining bee-produced compounds with the plant-produced resins, as has recently been documented in wood ants [128]. This potentially adds another dynamic to the fact that glucose oxidase (a compound produced in the mandibular glands) has been found in propolis [7]. The assumption was that it was found in propolis simply as an artefact of handling, but perhaps this needs to be investigated more fully.

In particular, a series of studies has documented the role of one particular compound, $p$-coumaric acid [56]. P-coumaric acid is found in pollen and nectar but is also a common component of propolis worldwide [60,75]. The ingestion of $p$-coumaric acid by honey bees increases expression of detoxification genes and increases metabolism of common beekeeper-applied miticides [56]. In addition, bees fed a diet of $p$-coumaric and another phytochemical, quercetin, also exhibited increased lifespans in some cage scenarios and after exposure to pyrethroid insecticides, though effects 
were complex based on the addition of protein supplements [53]. It may be that the presence of propolis in the hive and compounds like $p$-coumaric acid actually primes the detoxification pathways so that, upon exposure to certain pesticides, the honey bee is more quickly and effectively able to induce a detoxification response [55]. Ingestion of propolis extracts also decreases mortality of bees exposed to aflatoxins produced by fungi like Aspergillus that naturally grow on stored pollen in combs within colonies [29]. These toxic compounds are detoxified by cytochrome P450 activation, which is induced after ingestion of propolis and propolis-related compounds. The big question remains of whether or not simply exposure to propolis in the nest environment has these effects, since honey bees are not thought to typically ingest it.

Other than the potential of propolis as a detoxifying agent or primer of detoxification pathways, another hypothesized mechanism that could influence honey bee longevity via antioxidant-related pathways regards increased resistance to oxidative stress. The free radical theory of aging $[129,130]$ bases the aging process on the production of reactive oxygen species (ROS) via typical cellular metabolism. These ROS result in the oxidation of lipids, proteins and even DNA, disrupting cellular membrane stability and eventually causing apoptosis. Aging, in some ways, is thought to be an accumulation of all of this damage due to oxidative stress. Propolis extracts, through various studies in mainly vertebrate models [131,132], have been shown to widely inhibit the formation of reactive oxygen species, which reduces oxidative damage to proteins, lipids and DNA (reviewed in [133]). Reducing damage from oxidative stress accumulation through diet, by consuming antioxidant rich foods or supplements has been sought as a way to reduce these effects of aging with limited success in humans [130]. However, antioxidants need to get into cells to quench ROS, so studies examining appropriate delivery mechanisms are important. Propolis, as a natural mixture rich in antioxidants, is certainly understudied in regard to its potential effects against oxidative stress. Impacts of oxidative stress are natural in the progression of aging even in honey bees [134-136] and are known to be influenced by the environmental conditions in which colonies are maintained [137]. Work on potential effects that propolis may have on colonies in a commercial beekeeping operation to help reduce possible impacts of some of the stressors, including oxidative stress, are important moving forward.

\section{Applications for the Beekeeping Community}

Several studies have now clearly documented the benefits of a propolis envelope, particularly an envelope naturally constructed by the bees, to bee health and immune system functioning. However, the effects of propolis enrichment in colonies managed in a commercial setting need to be explored more fully. The collection of resins to construct a natural propolis envelope is performed by a rare subset of foraging bees, so increased resin use should not negatively affect honey production, and, in fact, the opposite effect has actually been observed $[47,48]$. It is estimated that the number of resin foragers is less than $1 \%$ of the total number of foragers in the hive, but this may be influenced by the bees' genetics [138,139]. Resin collection is partly a genetic tendency and partly a demand-driven process [16,140,141]. How and what resin collectors detect inside the nest to determine the need for resin is not clear. When resin foragers encounter rough surfaces and gaps inside the hive, they respond by collecting more resin to seal these cracks in the nest architecture and resin foragers are more sensitive to tactile information [142]. Therefore, a colony of bees can be encouraged to build a natural propolis envelope within standard beekeeping equipment by modifying the inner walls of bee boxes. Commercial propolis traps can be cut to fit the four inside walls of the hive boxes and stapled with the smooth side of the trap facing the wood and the rough side facing the colony ([20]; Figure 2B). It is recommended to manage colonies using nine frames instead of ten when using this method due to the space required for the traps. If the inside of the bee box is built with unfinished, rough lumber, scraped briskly with a wire brush, or if small grooves are cut in the interior walls of the box, the bees will apply a layer of propolis in the grooves of rough surfaces, forming a natural propolis envelope.

With this in mind, however, we must consider how altering the nest structure can also potentially adversely affect colony dynamics. The initial experimental design for the studies on the long-term 
effects of the propolis envelope consisted of three treatments: colonies with no extra propolis (control), colonies with a propolis envelope (Figure 2B), and colonies fitted with a propolis trap on top of the frames of the top box, as is done to collect propolis commercially. Bees from colonies with the propolis traps on top of the frames showed inconsistent, and sometimes higher immune-related gene expression, compared to bees in the propolis envelope and control colonies [19]. Moreover, bees from colonies with a propolis trap on top of the frames had significantly higher levels of virus (DWV) compared to bees in control and propolis envelope colonies in September 2012, May 2013 and May 2014 (but, see [22], which shows reduction in DWV relative to the controls). The hypothesis is that the presence of the water-resistant propolis trap throughout the year on top of the colony could have altered the microenvironment of the colony (e.g., increasing humidity levels or affecting air circulation within the nest), leading to favorable conditions for the growth of pathogens and maybe viruses. Thus, it appears that leaving a propolis trap on top of a colony for a long period of time, and, especially over the winter, is not beneficial to bee health and is not recommended. Finally, there is no evidence that bees consume resins or propolis. We do not recommend that beekeepers feed propolis solution to bees until studies adequately address the long-term effects of such a treatment. Because of the highly antibacterial and antifungal properties of propolis, it could risk poisoning bees and killing the beneficial microbiome in bees' guts that is also so critical to their health and survival $[27,82]$.

\section{Conclusions}

Honey bees collect plant-produced antimicrobial compounds and incorporate them into the nest environment. Honey bees, other social and solitary insects, and even some vertebrates co-opt these defensive compounds as their own form of defense. The specific role that this behavior plays in behavioral immunity is ripe for study. Here, we have described recent work that has been done on the interactions between propolis, the honey bee immune system, and honey bee pathogens, parasites and pests. Managed honey bee colonies are currently experiencing high rates of annual mortality, largely due to pathogens, parasites, pesticides and poor nutrition. Perhaps propolis can, at least in part, help mitigate effects from these threats. Understanding the role that propolis plays as a social immune defense directly against parasites and pathogens and through subtle, indirect effects on individual immunity and detoxification enzymes could be a key part of the puzzle to improve bee health. More research needs to be conducted on the long-term effects on the role of propolis on colony health and productivity in order to garner support from the beekeeping community to start selecting for propolis collection in the U.S., something that has been historically, and likely passively, selected against because of its sticky nature. In this way, propolis can be one part of an effective strategy to improve selection in U.S. stocks for resistance traits.

Acknowledgments: This research was funded by the National Science Foundation IOS 0717530 and IOS 1256992 to Marla Spivak, and the National Honey Board, Project Apis m, and the California State Beekeeping Association to Renata S. Borba and Marla Spivak. Funding was received to cover costs of publishing in open access.

Conflicts of Interest: The authors declare no conflict of interest.

\section{References}

1. Evans, J.D.; Schwarz, R.S. Bees brought to their knees: Microbes affecting honey bee health. Trends Microbiol. 2011, 19, 614-620. [CrossRef] [PubMed]

2. Sánchez-Bayo, F.; Goulson, D.; Pennacchio, F.; Nazzi, F.; Goka, K.; Desneux, N. Are bee diseases linked to pesticides?-A brief review. Environ. Int. 2016, 89-90, 7-11. [CrossRef] [PubMed]

3. vanEngelsdorp, D.; Meixner, M.D. A historical review of managed honey bee populations in europe and the united states and the factors that may affect them. J. Invertebr. Pathol. 2010, 103, S80-S95. [CrossRef] [PubMed]

4. Seitz, N.; Traynor, K.S.; Steinhauer, N.; Rennich, K.; Wilson, M.E.; Ellis, J.D.; Rose, R.; Tarpy, D.R.; Sagili, R.R.; Caron, D.M.; et al. A national survey of managed honey bee 2014-2015 annual colony losses in the USA. J. Apic. Res. 2015, 54, 292-304. [CrossRef] 
5. Simone-Finstrom, M.; Spivak, M. Propolis and bee health: The natural history and significance of resin use by honey bees. Apidologie 2010, 41, 295-311. [CrossRef]

6. Meyer, W. The propolis bees and their activities. Z. Bienenforsch. 1954, 2, 185-200. [CrossRef]

7. Zhang, C.-P.; Zheng, H.-Q.; Hu, F.-L. Extraction, partial characterization, and storage stability of $\beta$-glucosidase from propolis. J. Food Sci. 2011, 76, C75-C79. [CrossRef] [PubMed]

8. Castella, G.; Chapuisat, M.; Christe, P. Prophylaxis with resin in wood ants. Anim. Behav. 2008, 75, 1591-1596. [CrossRef]

9. Leonhardt, S.D.; Bluthgen, N. A sticky affair: Resin collection by bornean stingless bees. Biotropica 2009, 41, 730-736. [CrossRef]

10. Seeley, T.D.; Morse, R.A. Nest of the honey bee (Apis mellifera L.). Insectes Soc. 1976, 23, 495-512. [CrossRef]

11. Seeley, T.D.; Seeley, R.H.; Akratanakul, P. Colony defense strategies of the honeybees in thailand. Ecol. Monogr. 1982, 52, 43-63. [CrossRef]

12. Visscher, P.K. Adaptations of honey bees (Apis mellifera) to problems of nest hygiene. Sociobiology 1980, 5, 249-260.

13. Clark, E.H. Constructive Beekeeping; Ulsaker Printing Company: Fargo, ND, USA, 1918; p. 52.

14. Simone, M.; Evans, J.D.; Spivak, M. Resin collection and social immunity in honey bees. Evolution 2009, 63, 3016-3022. [CrossRef] [PubMed]

15. Bastos, E.M.A.F.; Simone, M.; Macedo Jorge, D.; Egea Soares, A.E.; Spivak, M. In vitro study of the antimicrobial activity of brazilian propolis against Paenibacillus larvae. J. Invertebr. Pathol. 2008, 97, $273-281$. [CrossRef] [PubMed]

16. Simone-Finstrom, M.D.; Spivak, M. Increased resin collection after parasite challenge: A case of self-medication in honey bees? PLoS ONE 2012, 7, e34061. [CrossRef] [PubMed]

17. Wilson, M.B.; Spivak, M.; Hegeman, A.D.; Rendahl, A.; Cohen, J.D. Metabolomics reveals the origins of antimicrobial plant resins collected by honey bees. PLoS ONE 2013, 8, e77512. [CrossRef] [PubMed]

18. Nicodemo, D.; Malheiros, E.B.; De Jong, D.; Couto, R.H.N. Increased brood viability and longer lifespan of honeybees selected for propolis production. Apidologie 2014, 45, 269-275. [CrossRef]

19. Borba, R.S. Constitutive and Therapeutic Benefits of Plant Resins and a Propolis Envelope to Honey Bee, Apis mellifera L., Immunity and Health. Ph.D. Thesis, University of Minnesota, Ann Arbor, MA, USA, 2015.

20. Borba, R.S.; Klyczek, K.K.; Mogen, K.L.; Spivak, M. Seasonal benefits of a natural propolis envelope to honey bee immunity and colony health. J. Exp. Biol. 2015, 218, 3689-3699. [CrossRef] [PubMed]

21. Wilson, M.B.; Brinkman, D.; Spivak, M.; Gardner, G.; Cohen, J.D. Regional variation in composition and antimicrobial activity of us propolis against Paenibacillus larvae and Ascosphaera apis. J. Invertebr. Pathol. 2015, 124, 44-50. [CrossRef] [PubMed]

22. Drescher, N.; Klein, A.-M.; Neumann, P.; Yañez, O.; Leonhardt, S. Inside honeybee hives: Impact of natural propolis on the ectoparasitic mite Varroa destructor and viruses. Insects 2017, 8, 15. [CrossRef] [PubMed]

23. Cremer, S.; Armitage, S.A.O.; Schmid-Hempel, P. Social immunity. Curr. Biol. 2007, 17, R693-R702. [CrossRef] [PubMed]

24. Meunier, J. Social immunity and the evolution of group living in insects. Philos. Trans. R. Soc. B-Biol. Sci. 2015, 370, 10. [CrossRef] [PubMed]

25. Schmid-Hempel, P. Parasites in Social Insects; Princeton University Press: Princeton, NJ, USA, 1998.

26. Evans, J.D.; Lopez, D.L. Bacterial probiotics induce an immune response in the honey bee (hymenoptera: Apidae). J. Econ. Entomol. 2004, 97, 752-756. [CrossRef] [PubMed]

27. Anderson, K.E.; Sheehan, T.H.; Eckholm, B.J.; Mott, B.M.; DeGrandi-Hoffman, G. An emerging paradigm of colony health: Microbial balance of the honey bee and hive (Apis mellifera). Insectes Soc. 2011, 58, 431-444. [CrossRef]

28. Evans, J.D.; Aronstein, K.; Chen, Y.P.; Hetru, C.; Imler, J.L.; Jiang, H.; Kanost, M.; Thompson, G.J.; Zou, Z.; Hultmark, D. Immune pathways and defence mechanisms in honey bees Apis mellifera. Insect Mol. Biol. 2006, 15, 645-656. [CrossRef] [PubMed]

29. Niu, G.; Johnson, R.M.; Berenbaum, M.R. Toxicity of mycotoxins to honeybees and its amelioration by propolis. Apidologie 2011, 42, 79-87. [CrossRef]

30. Schmid-Hempel, P. Evolutionary ecology of insect immune defenses. Annu. Rev. Entomol. 2005, 50, 529-551.

[CrossRef] [PubMed] 
31. Evans, J.D.; Pettis, J.S. Colony-level impacts of immune responsiveness in honey bees, Apis mellifera. Evolution 2005, 59, 2270-2274. [CrossRef] [PubMed]

32. Moret, Y.; Schmid-Hempel, P. Survival for immunity: The price of immune system activation for bumblebee workers. Science 2000, 290, 1166-1168. [CrossRef] [PubMed]

33. Wilson-Rich, N.; Spivak, M.; Fefferman, N.H.; Starks, P.T. Genetic, individual, and group facilitation of disease resistance in insect societies. Annu. Rev. Entomol. 2009, 54, 405-423. [CrossRef] [PubMed]

34. Simone-Finstrom, M. Social immunity and the superorganism: Behavioral defenses protecting honey bee colonies from pathogens and parasites. Bee World 2017, 94, 21-29. [CrossRef]

35. Erler, S.; Moritz, R.F. Pharmacophagy and pharmacophory: Mechanisms of self-medication and disease prevention in the honeybee colony (Apis mellifera). Apidologie 2016, 47, 389-411. [CrossRef]

36. Christe, P.; Oppliger, A.; Bancala, F.; Castella, G.; Chapuisat, M. Evidence for collective medication in ants. Ecol. Lett. 2003, 6, 19-22. [CrossRef]

37. Castella, G.; Chapuisat, M.; Moret, Y.; Christe, P. The presence of conifer resin decreases the use of the immune system in wood ants. Ecol. Entomol. 2008, 33, 408-412. [CrossRef]

38. Chapuisat, M.; Oppliger, A.; Magliano, P.; Christe, P. Wood ants use resin to protect themselves against pathogens. Proc. R. Soc. B-Biol. Sci. 2007, 274, 2013-2017. [CrossRef] [PubMed]

39. Park, Y.K.; Paredes-Guzman, J.F.; Aguiar, C.L.; Alencar, S.M.; Fujiwara, F.Y. Chemical constituents in Baccharis dracunculifolia as the main botanical origin of southeastern brazilian propolis. J. Agric. Food Chem. 2004, 52, 1100-1103. [CrossRef] [PubMed]

40. Bankova, V.; Boudourova-Krasteva, G.; Popov, S.; Sforcin, J.M.; Funari, S.R.C. Seasonal variations of the chemical composition of brazilian propolis. Apidologie 1998, 29, 361-367. [CrossRef]

41. Sforcin, J.; Fernandes, A.; Lopes, C.; Bankova, V.; Funari, S. Seasonal effect on brazilian propolis antibacterial activity. J. Ethnopharmacol. 2000, 73, 243-249. [CrossRef]

42. Engels, W.; Kaatz, H.; Zillikens, A.; Simões, Z.P.; Trube, A.; Braun, R.; Dittrich, F. Honey bee reproduction: Vitellogenin and caste-specific regulation of fertility. In Honey Bee Reproduction: Vitellogenin and Caste-Specific Regulation of Fertility; Elsevier Science Publishers B.V.: Amsterdam, The Netherlands, 1990; pp. 495-502.

43. Amdam, G.V.; Norberg, K.; Hagen, A.; Omholt, S.W. Social exploitation of vitellogenin. Proc. Natl. Acad. Sci. USA 2003, 100, 1799-1802. [CrossRef] [PubMed]

44. Amdam, G.V.; Simões, Z.L.; Hagen, A.; Norberg, K.; Schrøder, K.; Mikkelsen, Ø.; Kirkwood, T.B.; Omholt, S.W. Hormonal control of the yolk precursor vitellogenin regulates immune function and longevity in honeybees. Exp. Gerontol. 2004, 39, 767-773. [CrossRef] [PubMed]

45. Smart, M.; Pettis, J.; Rice, N.; Browning, Z.; Spivak, M. Linking measures of colony and individual honey bee health to survival among apiaries exposed to varying agricultural land use. PLoS ONE 2016, 11, e0152685. [CrossRef] [PubMed]

46. Garcia, C.R.; Oliveira, N.T.E.; Camargo, S.C.; Pires, B.G.; Oliveira, C.A.L.; Teixeira, R.A.; Pickler, M.A. Honey and propolis production, hygiene and defense behaviors of two generations of africanized honey bees. Sci. Agric. 2013, 70, 74-81. [CrossRef]

47. Manrique, A.J.; Soares, A.E.E. Start of africanized honey bee selection program for increased propolis production and its effect on honey production. Interciencia 2002, 27, 312-316.

48. Nicodemo, D.; De Jong, D.; Couto, R.H.N.; Malheiros, E.B. Honey bee lines selected for high propolis production also have superior hygienic behavior and increased honey and pollen stores. Genet. Mol. Res. 2013, 12, 6931-6938. [CrossRef] [PubMed]

49. Padilha, A.H.; Sattler, A.; Cobuci, J.A.; McManus, C.M. Genetic parameters for five traits in africanized honeybees using bayesian inference. Genet. Mol. Biol. 2013, 36, 207-213. [CrossRef] [PubMed]

50. Simone-Finstrom, M.; Hayworth, M. USDA-ARS Honey Bee Breeding, Genetics, and Physiology Laboratory, Baton Rouge, LA 70820, USA. Unpublished data. 2012.

51. Mallon, E.B.; Brockmann, A.; Schmid-Hempel, P. Immune response inhibits associative learning in insects. Proc. R. Soc. B-Biol. Sci. 2003, 270, 2471-2473. [CrossRef] [PubMed]

52. Richard, F.J.; Aubert, A.; Grozinger, C.M. Modulation of social interactions by immune stimulation in honey bee, Apis mellifera, workers. BMC Biol. 2008, 6. [CrossRef] [PubMed]

53. Liao, L.-H.; Wu, W.-Y.; Berenbaum, M. Impacts of dietary phytochemicals in the presence and absence of pesticides on longevity of honey bees (Apis mellifera). Insects 2017, 8, 22. [CrossRef] [PubMed] 
54. Schmittgen, T.D.; Livak, K.J. Analyzing real-time pcr data by the comparative ct method. Nat. Protoc. 2008, 3, 1101-1108. [CrossRef] [PubMed]

55. Johnson, R.M.; Mao, W.; Pollock, H.S.; Niu, G.; Schuler, M.A.; Berenbaum, M.R. Ecologically appropriate xenobiotics induce cytochrome p450s in Apis mellifera. PLoS ONE 2012, 7, e31051. [CrossRef] [PubMed]

56. Mao, W.; Schuler, M.A.; Berenbaum, M.R. Honey constituents up-regulate detoxification and immunity genes in the western honey bee Apis mellifera. Proc. Natl. Acad. Sci. USA 2013, 110, 8842-8846. [CrossRef] [PubMed]

57. Westra, E.R.; van Houte, S.; Oyesiku-Blakemore, S.; Makin, B.; Broniewski, J.M.; Best, A.; Bondy-Denomy, J.; Davidson, A.; Boots, M.; Buckling, A. Parasite exposure drives selective evolution of constitutive versus inducible defense. Curr. Biol. 2015, 25, 1043-1049. [CrossRef] [PubMed]

58. Burdock, G.A. Review of the biological properties and toxicity of bee propolis. Food Chem. Toxicol. 1998, 36, 347-363. [CrossRef]

59. Bankova, V.; Marcucci, M.C. Standardization of propolis: Present status and perspectives. Bee World 2000, 81, 182-188. [CrossRef]

60. Bankova, V.S.; de Castro, S.L.; Marcucci, M.C. Propolis: Recent advances in chemistry and plant origin. Apidologie 2000, 31, 3-15. [CrossRef]

61. Sforcin, J.M.; Bankova, V. Propolis: Is there a potential for the development of new drugs? J. Ethnopharmacol. 2011, 133, 253-260. [CrossRef] [PubMed]

62. Silva-Carvalho, R.; Baltazar, F.; Almeida-Aguiar, C. Propolis: A complex natural product with a plethora of biological activities that can be explored for drug development. Evid.-Based Complement. Alternat. Med. 2015, 2015, 206439. [CrossRef] [PubMed]

63. Huang, S.; Zhang, C.-P.; Wang, K.; Li, G.Q.; Hu, F.-L. Recent advances in the chemical composition of propolis. Molecules 2014, 19, 19610-19632. [CrossRef] [PubMed]

64. Langenheim, J.H. Plant Resins: Chemistry, Evolution, Ecology and Ethnobiology; Timber Press: Portland, OR, USA, 2003; p. 586.

65. Alday, E.; Valencia, D.; Carreño, A.L.; Picerno, P.; Piccinelli, A.L.; Rastrelli, L.; Robles-Zepeda, R.; Hernandez, J.; Velazquez, C. Apoptotic induction by pinobanksin and some of its ester derivatives from sonoran propolis in a b-cell lymphoma cell line. Chem.-Biol. Interact. 2015, 242, 35-44. [CrossRef] [PubMed]

66. Cuesta-Rubio, O.; Frontana-Uribe, B.A.; Ramírez-Apan, T.; Cárdenas, J. Polyisoprenylated benzophenones in cuban propolis: Biological activity of nemorosone. Z. Naturforsch. C 2002, 57, 372-378. [CrossRef] [PubMed]

67. Aga, H.; Shibuya, T.; Sugimoto, T.; Kurimoto, M.; Nakajima, S. Isolation and identification of antimicrobial compounds in brazilian propolis. Biosci. Biotechnol. Biochem. 1994, 58, 945-946. [CrossRef]

68. Popova, M.P.; Chinou, I.B.; Marekov, I.N.; Bankova, V.S. Terpenes with antimicrobial activity from cretan propolis. Phytochemistry 2009, 70, 1262-1271. [CrossRef] [PubMed]

69. Salatino, A.; Weinstein Teixeira, W.; Negri, G.; Message, D. Origin and chemical variation of brazilian propolis. Evid. Based Complement. Alternat. Med. 2005, 2, 33-38. [CrossRef] [PubMed]

70. Siheri, W.; Igoli, J.O.; Gray, A.I.; Nasciemento, T.G.; Zhang, T.; Fearnley, J.; Clements, C.J.; Carter, K.C.; Carruthers, J.; Edrada-Ebel, R. The isolation of antiprotozoal compounds from libyan propolis. Phytother. Res. 2014, 28, 1756-1760. [CrossRef] [PubMed]

71. Bilikova, K.; Popova, M.; Trusheva, B.; Bankova, V. New anti-paenibacillus larvae substances purified from propolis. Apidologie 2013, 44, 278-285. [CrossRef]

72. Wilson, M.B.; Pawlus, A.D.; Brinkman, D.; Gardner, G.; Hegeman, A.D.; Spivak, M.; Cohen, J.D. 3-acyl dihydroflavonols from poplar resins collected by honey bees are active against the bee pathogens Paenibacillus larvae and Ascosphaera apis. Phytochemistry 2017, 138, 83-92. [CrossRef] [PubMed]

73. Voigt, K.; Rademacher, E. Effect of the propolis components, cinnamic acid and pinocembrin, on Apis mellifera and Ascosphaera apis. J. Apic. Sci. 2015, 59, 89-95. [CrossRef]

74. Ghisalberti, E.L. Propolis: A review. Bee World 1979, 60, 263-282. [CrossRef]

75. Marcucci, M.C. Propolis: Chemical composition, biological properties and therapeutic activity. Apidologie 1995, 26, 83-99. [CrossRef]

76. Gekker, G.; Hu, S.X.; Spivak, M.; Lokensgard, J.R.; Peterson, P.K. Anti-HIV-1 activity of propolis in CD4(+) lymphocyte and microglial cell cultures. J. Ethnopharmacol. 2005, 102, 158-163. [CrossRef] [PubMed]

77. Sforcin, J.M. Biological properties and therapeutic applications of propolis. Phytother. Res. 2016, 30, 894-905. [CrossRef] [PubMed] 
78. Drescher, N.; Wallace, H.M.; Katouli, M.; Massaro, C.F.; Leonhardt, S.D. Diversity matters: How bees benefit from different resin sources. Oecologia 2014, 176, 943-953. [CrossRef] [PubMed]

79. Lindenfelser, L.A. Antimicrobial activity of propolis. Am. Bee J. 1967, 107, 90-92.

80. Lindenfelser, L.A. In vivo activity of propolis against Bacillus larvae. J. Invertebr. Pathol. 1968, 12, $129-131$. [CrossRef]

81. Antunez, K.; Harriet, J.; Gende, L.; Maggi, M.; Eguaras, M.; Zunino, P. Efficacy of natural propolis extract in the control of american foulbrood. Vet. Microbiol. 2008, 131, 324-331. [CrossRef] [PubMed]

82. Tian, B.; Fadhil, N.H.; Powell, J.E.; Kwong, W.K.; Moran, N.A. Long-term exposure to antibiotics has caused accumulation of resistance determinants in the gut microbiota of honeybees. MBio 2012, 3. [CrossRef] [PubMed]

83. Messer, A.C. Fresh dipterocarp resins gathered by megachilid bees inhibit growth of pollen-associated fungi. Biotropica 1985, 17, 175-176. [CrossRef]

84. Garedew, A.; Lamprecht, I.; Schmolz, E.; Schricker, B. The varroacidal action of propolis: A laboratory assay. Apidologie 2002, 33, 41-50. [CrossRef]

85. Morse, R.; Flottum, K. Honey Bee Pests Predators and Diseases; AI Root Company: Medina, OH, USA, 1997.

86. Gilliam, M.; Taber, S.; Lorenz, B.J.; Prest, D.B. Factors affecting development of chalkbrood disease in colonies of honey bees, Apis mellifera, fed pollen contaminated with Ascosphaera apis. J. Invertebr. Pathol. 1988, 52, 314-325. [CrossRef]

87. Spivak, M.; Reuter, G.S. Resistance to american foulbrood disease by honey bee colonies (Apis mellifera) bred for hygienic behavior. Apidologie 2001, 32, 555-565. [CrossRef]

88. Rothenbuhler, W.C. Behaviour genetics of nest cleaning in honey bees. I. Responses of four inbred lines to disease-killed brood. Anim. Behav. 1964, 12, 578-583. [CrossRef]

89. Rothenbuhler, W.C.; Thompson, V.C. Resistance to american foulbrood in honey bees. I. Differential survival of larvae of different genetic lines. J. Econ. Entomol. 1956, 49, 470-475. [CrossRef]

90. Bambrick, J.F.; Rothenbuhler, W.C. Resistance to american foulbrood in honey bees. 4. Relationship between larval age at innoculation and mortality in a resistant and in a susceptible line. J. Invertebr. Pathol. 1961, 3 , 381-390.

91. Thompson, V.C.; Rothenbuhler, W.C. Resistance to american foulbrood in honey bees. Ii. Differential protection of larvae by adults of different genetic lines. J. Econ. Entomol. 1957, 50, 731-737. [CrossRef]

92. Rose, R.I.; Briggs, J.D. Resistance to american foulbrood in honey bees ix. Effects of honey-bee larval food on the growth and viability of Bacillus larvae. J. Invertebr. Pathol. 1969, 13, 74-80. [CrossRef]

93. Seeley, T.D.; Tarpy, D.R. Queen promiscuity lowers disease within honeybee colonies. Proc. R. Soc. B-Biol. Sci. 2007, 274, 67-72. [CrossRef] [PubMed]

94. de Graaf, D.C.; Alippi, A.M.; Antunez, K.; Aronstein, K.A.; Budge, G.; De Koker, D.; De Smet, L.; Dingman, D.W.; Evans, J.D.; Foster, L.J.; et al. Standard methods for american foulbrood research. J. Apic. Res. 2013, 52, 1-28. [CrossRef]

95. López-Uribe, M.M.; Fitzgerald, A.; Simone-Finstrom, M. Inducible versus constitutive social immunity: Examining effects of colony infection on glucose oxidase and Defensin-1 production in honey bees. $R$. Soc. Open Sci. 2017, accepted.

96. Gherman, B.I.; Denner, A.; Bobis, O.; Dezmirean, D.S.; Marghitas, L.A.; Schluens, H.; Moritz, R.F.A.; Erler, S. Pathogen-associated self-medication behavior in the honeybee Apis mellifera. Behav. Ecol. Sociobiol. 2014, 68, 1777-1784. [CrossRef]

97. Cox-Foster, D.L.; Conlan, S.; Holmes, E.C.; Palacios, G.; Evans, J.D.; Moran, N.A.; Quan, P.-L.; Briese, T.; Hornig, M.; Geiser, D.M.; et al. A metagenomic survey of microbes in honey bee colony collapse disorder. Science 2007, 318, 283-287. [CrossRef] [PubMed]

98. Chen, Y.; Evans, J.D.; Smith, I.B.; Pettis, J.S. Nosema ceranae is a long-present and wide-spread microsporidian infection of the european honey bee (apis mellifera) in the united states. J. Invertebr. Pathol. 2008, 97, 186-188. [CrossRef] [PubMed]

99. Klee, J.; Besana, A.M.; Genersch, E.; Gisder, S.; Nanetti, A.; Tam, D.Q.; Chinh, T.X.; Puerta, F.; Ruz, J.M.; Kryger, P. Widespread dispersal of the microsporidian Nosema ceranae, an emergent pathogen of the western honey bee, Apis mellifera. J. Invertebr. Pathol. 2007, 96, 1-10. [CrossRef] [PubMed]

100. Yemor, T.; Phiancharoen, M.; Eric Benbow, M.; Suwannapong, G. Effects of stingless bee propolis on nosema ceranae infected asian honey bees, apis cerana. J. Apic. Res. 2015, 54, 468-473. [CrossRef] 
101. Suwannapong, G.; Maksong, S.; Benbow, M. Stingless bee propolis effects on experimental infection of apis florea with nosema ceranae. J. Agric. Sci. Technol. A 2011, 1, 818-825.

102. Kwong, W.K.; Moran, N.A. Gut microbial communities of social bees. Nat. Rev. Microbiol. 2016, 14, $374-384$. [CrossRef] [PubMed]

103. Garedew, A.; Schmolz, E.; Lamprecht, I. Microcalorimetric and respirometric investigation of the effect of temperature on the antivarroa action of the natural bee product-propolis. Thermochim. Acta 2003, 399, 171-180. [CrossRef]

104. Damiani, N.; Daniel Maggi, M.; Brenda Gende, L.; Faverin, C.; Javier Eguaras, M.; Augusto Marcangeli, J. Evaluation of the toxicity of a propolis extract on Varroa destructor (acari: Varroidae) and Apis mellifera (hymenoptera: Apidae). J. Apic. Res. 2010, 49, 257-264. [CrossRef]

105. Damiani, N.; Fernandez, N.J.; Maldonado, L.M.; Alvarez, A.R.; Eguaras, M.J.; Marcangeli, J.A. Bioactivity of propolis from different geographical origins on Varroa destructor (acari: Varroidae). Parasitol. Res. 2010, 107, 31-37. [CrossRef] [PubMed]

106. Popova, M.; Reyes, M.; Le Conte, Y.; Bankova, V. Propolis chemical composition and honeybee resistance against Varroa destructor. Nat. Prod. Res. 2014, 28, 788-794. [CrossRef] [PubMed]

107. Johnson, K.; Eischen, F.; Giannasi, D. Chemical composition of north american bee propolis and biological activity towards larvae of greater wax moth (lepidoptera: Pyralidae). J. Chem. Ecol. 1994, 20, 1783-1791. [CrossRef] [PubMed]

108. Garedew, A.; Schmolz, E.; Lamprecht, I. Effect of the bee glue (propolis) on the calorimetrically measured metabolic rate and metamorphosis of the greater wax moth Galleria mellonella. Thermochim. Acta 2004, 413, 63-72. [CrossRef]

109. Shaver, T.; Lukefahr, M. Effect of flavonoid pigments and gossypol on growth and development of the bollworm, tobacco budworm, and pink bollworm. J. Econ. Entomol. 1969, 62, 643-646. [CrossRef]

110. Kato, M. Phenols as indispensible components of the synthetic diet of the silkworm, Bombyx mori. Entomol. Exp. Appl. 1978, 24, 485-490. [CrossRef]

111. Neumann, P.; Pirk, C.; Hepburn, H.; Solbrig, A.; Ratnieks, F.; Elzen, P.; Baxter, J. Social encapsulation of beetle parasites by cape honeybee colonies (Apis mellifera capensis esch.). Naturwissenschaften 2001, 88, 214-216. [PubMed]

112. Ellis, J.D.; Hepburn, H.R. A note on mapping propolis deposits in cape honey bee (Apis mellifera capensis) colonies. Afr. Entomol. 2003, 11, 122-124.

113. Ellis, J. Life behind bars: Why honey bees feed small hive beetles. Am. Bee J. 2002, 142, 267-269.

114. Ellis, J.D.; Hepburn, H.R.; Ellis, A.M.; Elzen, P.J. Social encapsulation of the small hive beetle (Aethina tumida murray) by european honeybees (Apis mellifera L.). Insectes Soc. 2003, 50, 286-291. [CrossRef]

115. Hoyt, M. The World of Bees; Coward McCann Inc.: New York, NY, USA, 1965.

116. Bogdanov, S. Contaminants of bee products. Apidologie 2006, 37, 1-18. [CrossRef]

117. Bogdanov, S.; Kilchenmann, V.; Imdorf, A. Acaricide residues in some bee products. J. Apic. Res. 1998, 37, 57-67. [CrossRef]

118. Wallner, K. Varroacides and their residues in bee products. Apidologie 1999, 30, 235-248. [CrossRef]

119. Zhou, J.; Xue, X.; Li, Y.; Zhang, J.; Chen, F.; Wu, L.; Chen, L.; Zhao, J. Multiresidue determination of tetracycline antibiotics in propolis by using hplc-uv detection with ultrasonic-assisted extraction and two-step solid phase extraction. Food Chem. 2009, 115, 1074-1080. [CrossRef]

120. Chen, F.; Chen, L.; Wang, Q.; Zhou, J.; Xue, X.; Zhao, J. Determination of organochlorine pesticides in propolis by gas chromatography-electron capture detection using double column series solid-phase extraction. Anal. Bioanal. Chem. 2009, 393, 1073-1079. [CrossRef] [PubMed]

121. Pérez-Parada, A.; Colazzo, M.; Besil, N.; Geis-Asteggiante, L.; Rey, F.; Heinzen, H. Determination of coumaphos, chlorpyrifos and ethion residues in propolis tinctures by matrix solid-phase dispersion and gas chromatography coupled to flame photometric and mass spectrometric detection. J. Chromatogr. A 2011, 1218, 5852-5857. [CrossRef] [PubMed]

122. Acosta-Tejada, G.M.; Medina-Peralta, S.; Moguel-Ordóñez, Y.B.; Muñoz-Rodríguez, D. Matrix solid-phase dispersion extraction of organophosphorus pesticides from propolis extracts and recovery evaluation by gc/ms. Anal. Bioanal. Chem. 2011, 400, 885-891. [CrossRef] [PubMed] 
123. dos Santos, T.F.S.; Aquino, A.; Dórea, H.S.; Navickiene, S. Mspd procedure for determining buprofezin, tetradifon, vinclozolin, and bifenthrin residues in propolis by gas chromatography-mass spectrometry. Anal. Bioanal. Chem. 2008, 390, 1425-1430. [CrossRef] [PubMed]

124. Johnson, R.M. Honey bee toxicology. Annu. Rev. Entomol. 2015, 60, 415-434. [CrossRef] [PubMed]

125. Frazier, M.; Mullin, C.; Frazier, J.; Ashcraft, S. What have pesticides got to do with it? Am. Bee J. 2008, 148, 521-524.

126. vanEngelsdorp, D.; Evans, J.D.; Donovall, L.; Mullin, C.; Frazier, M.; Frazier, J.; Tarpy, D.R.; Hayes, J., Jr.; Pettis, J.S. "Entombed pollen": A new condition in honey bee colonies associated with increased risk of colony mortality. J. Invertebr. Pathol. 2009, 101, 147-149. [CrossRef] [PubMed]

127. Tautz, J. The Buzz about Bees: Biology of a Superorganism; Springer: Berlin, Germany, 2008.

128. Brütsch, T.; Jaffuel, G.; Vallat, A.; Turlings, T.C.J.; Chapuisat, M. Wood ants produce a potent antimicrobial agent by applying formic acid on tree-collected resin. Ecol. Evol. 2017, 7, 2249-2254. [CrossRef] [PubMed]

129. Harman, D. Aging: A theory based on free radical and radiation chemistry. J. Gerontol. 1956, 11, $298-300$. [CrossRef] [PubMed]

130. Camici, G.G.; Shi, Y.; Cosentino, F.; Francia, P.; Luscher, T.F. Anti-aging medicine: Molecular basis for endothelial cell-targeted strategies-A mini-review. Gerontology 2011, 57, 101-108. [CrossRef] [PubMed]

131. Yonar, S.M.; Ural, M.S.; Silici, S.; Yonar, M.E. Malathion-induced changes in the haematological profile, the immune response, and the oxidative/antioxidant status of cyprinus carpio carpio: Protective role of propolis. Ecotoxicol. Environ. Saf. 2014, 102, 202-209. [CrossRef] [PubMed]

132. Ichikawa, H.; Satoh, K.; Tobe, T.; Yasuda, I.; Ushio, F.; Matsumoto, K.; Endo, K.; Ookubo, C. Free radical scavenging activity of propolis. Redox Rep. 2002, 7, 347-350. [CrossRef] [PubMed]

133. Farooqui, T.; Farooqui, A.A. Beneficial effects of propolis on human health and neurological diseases. Front. Biosci. 2012, 4, 779-793. [CrossRef]

134. Seehuus, S.C.; Norberg, K.; Gimsa, U.; Krekling, T.; Amdam, G.V. Reproductive protein protects functionally sterile honey bee workers from oxidative stress. Proc. Natl. Acad. Sci. USA 2006, 103, 962-967. [CrossRef] [PubMed]

135. Li-Byarlay, H.; Huang, M.H.; Simone-Finstrom, M.; Strand, M.K.; Tarpy, D.R.; Rueppell, O. Honey bee (Apis mellifera) drones survive oxidative stress due to increased tolerance instead of avoidance or repair of oxidative damage. Exp. Gerontol. 2016, 83, 15-21. [CrossRef] [PubMed]

136. Williams, J.B.; Roberts, S.P.; Elekonich, M.M. Age and natural metabolically-intensive behavior affect oxidative stress and antioxidant mechanisms. Exp. Gerontol. 2008, 43, 538-549. [CrossRef] [PubMed]

137. Simone-Finstrom, M.; Li-Byarlay, H.; Huang, M.H.; Strand, M.K.; Rueppell, O.; Tarpy, D.R. Migratory management and environmental conditions affect lifespan and oxidative stress in honey bees. Sci. Rep. 2016, 6, 32023. [CrossRef] [PubMed]

138. Butler, C. The Honeybee: An Introduction to Her Sense-Physiology and Behaviour; Oxford University Press: London, UK, 1949.

139. Page, R.E.; Fondrk, M.K. The effects of colony-level selection on the social organization of honey bee (Apis mellifera L.) colonies: Colony-level components of pollen hoarding. Behav. Ecol. Sociobiol. 1995, 36, 135-144. [CrossRef]

140. Nakamura, J.; Seeley, T.D. The functional organization of resin work in honeybee colonies. Behav. Ecol. Sociobiol. 2006, 60, 339-349. [CrossRef]

141. Martinez, O.A.; Soares, A.E.E. Melhoramento genético na apicultura comercial para produção da própolis. Rev. Bras. Saúde Prod. Anim. 2012, 13, 982-990. [CrossRef]

142. Simone-Finstrom, M.; Gardner, J.; Spivak, M. Tactile learning in resin foraging honeybees. Behav. Ecol. Sociobiol. 2010, 64, 1609-1617. [CrossRef]

(C) 2017 by the authors. Licensee MDPI, Basel, Switzerland. This article is an open access article distributed under the terms and conditions of the Creative Commons Attribution (CC BY) license (http:/ / creativecommons.org/licenses/by/4.0/). 